特集 11

\title{
胃癌所属リンパ節の免疫組織学的解析
}

\begin{tabular}{|c|c|c|c|c|c|c|c|}
\hline \multicolumn{8}{|c|}{$\begin{array}{l}\text { 岡山大学医学部第 } 1 \text { 外科 } \\
\text { 香川医科大学病理* }\end{array}$} \\
\hline 岡林 & 孝弘 & 堀見 & 忠司 & 合地 & 明 & 小林 & 元壮 \\
\hline 武田 & 功 & 平松 & 聡 & 二宮 & 基樹 & 吉田 & 栄一 \\
\hline 長江 & 聡一 & 向井 & 晃太 & 金田 & 道弘 & 香川 & 茂雄 \\
\hline 田中 & 紀章 & 折田 & 薫三 & 小林 & 省二* & & \\
\hline
\end{tabular}

\section{IMMUNOHISTOCHEMICAL ANALYSIS ON REGIONAL LYMPH NODES OF GASTRIC CANCER}

\section{Takahiro OKABAYASHI, Tadashi HORIMI, Akira GOUCHI, Genso KOBAYASHI, Isao TAKEDA, Satoshi HIRAMATSU, Motoki NINOMIYA, Eiichi YOSHIDA, Soichi NAGAE, Kouta MUKAI, Michihiro KANEDA, Shigeo KAGAWA, Noriaki TANAKA, Kunzo ORITA and Shoji KOBAYASHI*}

The 1st Department of Surgery, Okayama University School of Medicine *Department of Pathology, Kagawa Medical College

寀引用語：胃癌所属リンパ節, 免疫組織学的染色, モノクローナル抗体

\section{1.はじめに}

消化器癌の手術では, 癌再発を予防するため, 所属 リンパ節郭清が必須のものと考兄られ，肉眼的に転移 陰性と思われるリンパ節に対しても拡大郭清が行われ ている. しかし，リンパ節の生体防禦的な免疫学的側 面の解析により，いかなる郭清がより適正であるかが 最近問題となってきだ. また，これらのリンパ節が免 疫学的なバリヤーの役割を果しているならば，それを 増強させる試みす当然行われるべきすのである2。.

そこで, 著者らは胃癌患者の所属リンパ節を用いて， 基礎的・臨床的な研究を行い,リンパ節の免度学的抗 腫場能の解析とリンパ節郭清について検討したので報 告する.

\section{2. 対象と方法}

1）リンパ節の免疫組織学的解析

※第26回日消外総会シンボII：消化器癌リンパ節応答 とその郭清

$<1985$ 年11月12日受理 >別刷請求先：岡林 孝弘 于700 岡山市鹿田町 2-5-1 岡山大学医学部第 1 外科
胃癌手術例24例の所属リンパ節計52個を対象とし， 良性疾患手術例 2 例の胃所属リンパ節 3 個を正常対照 例とした。

リンバ節を OCT compound で包埋後, 液体窒素中 で急速凍結し, $5 \mu \mathrm{m}$ の凍結切片に薄切して兔疫組織学 的検索を行った，すなわち，免疫担当細胞サブセット に対応する各種のモノクローナル抗体（表 1) を一次 抗体とし, Vector 社 $\mathrm{ABC}$ キットを用いて, $\mathrm{ABC}$ 法 ${ }^{3)}$ による酵素抗体染色を行った，表 1 のほかに，一部の 症例には, 抗 interleukin-2 (IL-2) receptor モノク ローナル抗体を活性化 T細胞の免疫組織学的検索に使 用した。ペルオキシダーゼ反応用として，3，3' Diaminobenzidine 4HCl (DAB) を使用した。

さらに, OKT8陽性細胞 (以下 OKT8+細胞) すなわ ち suppressor/cytotoxic T 細胞について,より詳細な 機能的サブセット解析のため, Leu15モノクローナル 抗体を使用し，鉴光抗体法を組み合わせた組織二重染 色法4を試みた。すすなわち, Leu2a ${ }^{+}$-Leu15+細胞は suppressor $\mathrm{T}$ 細胞を示 ${ }^{5)}$, Leu2 $\mathrm{a}^{+} \cdot$ Leu15-細胞は cytotoxic $\mathrm{T}$ 細胞を示す6). 
表 1 使用したモノクローナル抗体および反応する細 胞群

\begin{tabular}{|c|c|}
\hline $\begin{array}{l}\text { Monoclonal } \\
\text { antibody }\end{array}$ & Spencificity \\
\hline OKT3 & peripheral $T$ lymphocytes \\
\hline OKT 4 & helper/inducer $\mathrm{T}$ lymphocytes \\
\hline OKT6 & common thymocytes, Langerhans celis \\
\hline OKT8 & suppressor/cytotoxic $T$ lymphocytes \\
\hline OKT 10 & $\begin{array}{l}\text { precursor cells,activated lymphocy- } \\
\text { tes, circulating null cells }\end{array}$ \\
\hline OKM1 & monocytes,null cells,granulocytes \\
\hline OKla 1 & $\begin{array}{l}\text { B lymphocytes,activated } T \text { lymph- } \\
\text { ocytes,some monocytes, Langerhans } \\
\text { cells,interdigitating dendritic cells }\end{array}$ \\
\hline Leut & LGL,NK/K cells \\
\hline Leu 10 & $\begin{array}{l}\text { B lymphocytes,monocytes, } \\
\text { interdigitating dendritic cells }\end{array}$ \\
\hline Let $11 \mathrm{~b}$ & NK cells, neutrophils, basophils \\
\hline Lou12 & B lymphocytes: \\
\hline
\end{tabular}

2) 術前免疫賦活剂腫瘍内投与の検榙

免疫賦活剂 OK-432あるいはPSKを術前10１4日 前に経内視鏡的に腫瘍内投与した胃癌症例で，所属り ンパ節のリンバ節反応様式を検討し，また，免疫組織 学的検索を行った。

さらに, OK-432腫瘍内投与例のリンパ節リンパ球を 用いて, in vitroで K-562をターゲットとする single cell assay を行い, killer 細胞の出現率を測定し, 細胞 障害活性について検索した。

3) 生存率の検討

胃癌治癒切除例 stage III における OK-432術前腫瘍 内投与群と非投与群で，2年生存率を比較した。京た， リンパ節郭清度（Rナンバー）別の予後を検討するた め, 昭和51年から53年の 3 年間の当科における胃癌治 癒切除例のうち, 組織学的リンパ節転移度 $\mathrm{n}_{0}$ 例扣よび $\mathrm{n}_{1}$ 例で， Rナンバー別に 5 年生存率を比較した。

\section{3. 結 果}

1)リンパ節の免疫組織学的解析

リンパ節内領域に掞ける各モノクローナル抗体陽性 細胞の分布様式は，対照の良性疾患リンパ節抢よび胃 癌所属リンパ節ともに医ぼ同様で，著変は認めなかっ た7).

また，胃癌取り扱い規約 ${ }^{8}$ による第 1 群と第 3 群り ンパ節で, OKT3, OKT4, OKT8, OKT10, OKIal 各 陽性細胞数および OKT4/OKT8比を検索した所, 第 3 群リンパ節は第 1 群リンパ節に比較して paracortical area および sinusともに $\mathrm{OKT}^{+}$細胞, OKT4 $4^{+}$細胞, $\mathrm{OKIal}^{+}$細胞および OKT4/OKT8比が増加を示し， $\mathrm{OKT} 8^{+}$細胞には変化がみられず, OKT10+細胞は減少
図 1 胃癌所属第 1 群少よび第 3 群リンパ節における 各モノクローナル抗体陽珄細胞数の比較 paracortical area $と$ sinusにおける OKT3, OKT4, OKT8，OKT10，OKIal 各陽性細胞数および OKT4/OKT8比を第 1 群リンパ節と第 3 群リンパ 節で比較した.

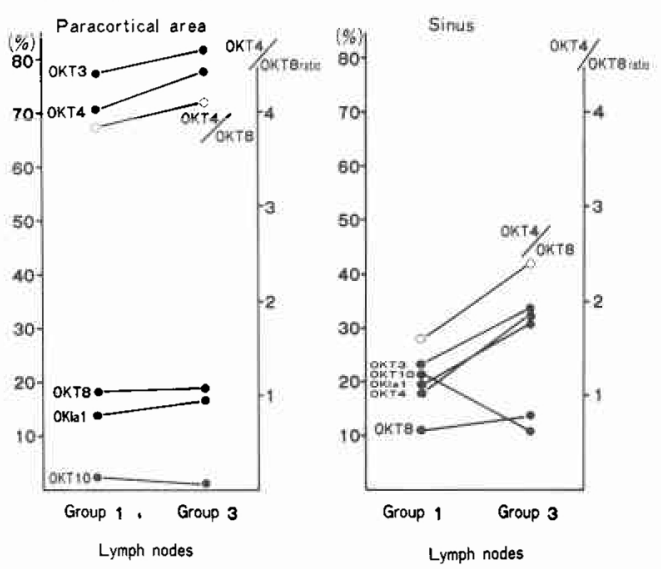

を示した（図 1)。高た，転移陽性リンパ節では，転移 陰性リンパ節に比較して，OKT4+細胞の减少および OKT8+細胞の増加がみられだ).

natural killer 細胞（以下 NK 細胞）と反応する Leu7, Leu11b 各陽性細胞は, 第 1 群, 第 3 群の転移陽 性および陰性リンパ節ではいずれも少数しかみられな かったが，分布様式は異なっていた。すなわち，Leu7 $7^{+}$ 細胞の多〈は germinal center に存在するが9), Leul1 $\mathrm{b}^{+}$細胞は germinal center にみられず，germinal center 以外に少数認められ, OKM1+細胞や Leu15 細胞 の分布形態と岡様であった。

次に転移陰性りンパ節で, Leu2a (OKT8) をFITC で緑に, Leu15を phycoerythrin で赤に, 組織二重染色 した結果, Leu2a+で Leu15+の suppressor T 細胞は任 とんど認められず，Leu $2 \mathrm{a}^{+}$細胞の大多数は Leu15-で あった。しかしながら，転移陽性リンパ節では，転移 癌巣の周冊で，Leu $2 a^{+}-$Leu $15^{+}$と判定できるリンパ球 が認められた（写真 1 ).

2) 術前免疫賦活剂腫瘍内投与の検討

$\mathrm{n}_{0}$ 症例に㧍けるリンパ節反応様式を第 1 群, 2 群, 3 群リンパ節ごとに検討したところ，pm 早期死亡群で は sinus histiocytosis の頻度が第 3 群リンパ節で低下 し, follicular hyperplasia は第 3 群リンパ節で増大し ていた，一方，術前免疫賦活剂 OK-432あるいは PSK 腫瘍内投与群では， sinus histiocytosisおよび par- 
写真 1 転移陽性リンパ節の Leu2a と Leu15による 組織二重染色法

Leu2a+細胞はB 励起で FITCが緑に，Leu15+細胞 は G 励起で phycoerythrinが赤にそれぞれ萤光を 発するが, 一部 ( $\rightarrow$ ) のンパ球は Leu2a ${ }^{+}$Leu15 ${ }^{+}$ の suppressor T 細胞であるらと判定できた。

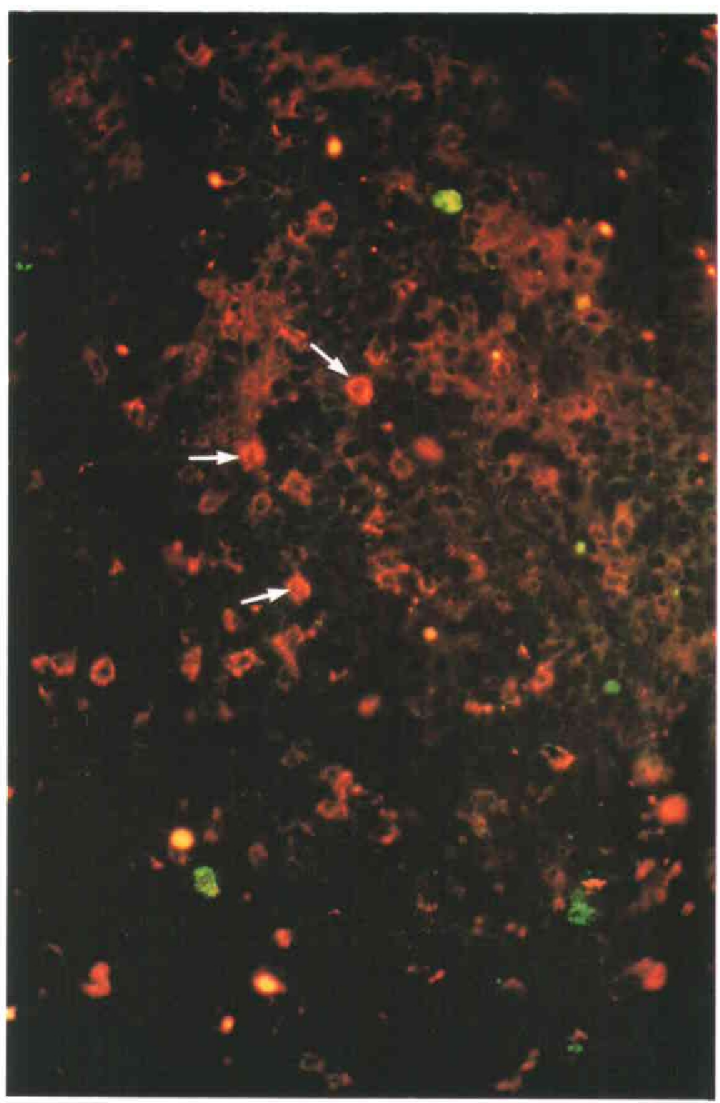

图 2 免疫賦活剂腫瘍内投与例 $\left(\mathrm{n}_{0}\right.$ 症例)のリンバ節反 応㥞式

OK-432投与群およびPSK 投与群のリンパ節反灾 様式を非投与例の $\mathrm{pm}$ 早期死亡群と比較した。

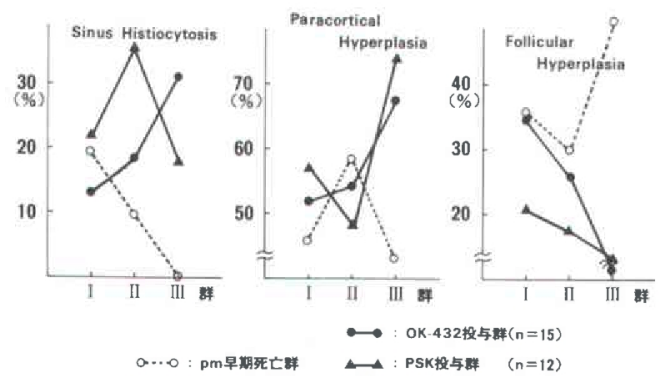

acortical hyperplasia が第 3 群りンパ節でも認めら れ, follicular hyperplasia は第 3 群リンパ節で減少を 示した（図2).

これらの免疫組織学的検索では, OK-432腫瘍内投与 群で, IL-2 receptor ${ }^{+}$細胞が paracortical area で著 明な増加を示す例(写真 2 )や, PSK 投与群で, $\mathrm{OKM} 1^{+}$ 細胞㧍よび OKT4+ 細胞の増加傾向がそれぞれ認めら れた。

また， single cell assay の結果，OK-432腫瘍内投与 例では非投与例に比較して，第 3 群，第 4 群リンパ節

写真 2 OK-432腫殖内投与例所属リンパ節の抗 IL-2 receptor 抗体による $\mathrm{ABC}$ 法

(メチルグリーン核染色)

paracortical areaに散在して陽性細胞が認められ る.

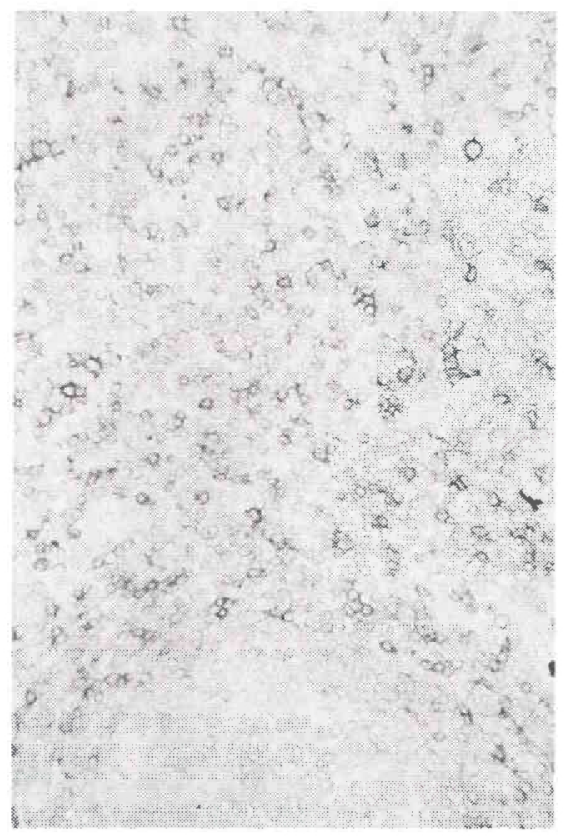

図 3 胃癌所属リンパ節リンハ球の single cell assay による killer 細胞の出現率

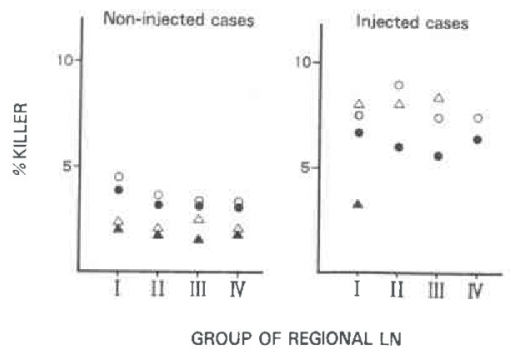


にまで，紐胞障害活性の誘導が認められた（図 3 ）。

3）生存率の検討

OK-432腫場内投与群の 2 年生存率は, 非投与群より 良好であったが, $\mathrm{n}(-)$ 群と $\mathrm{n}(+)$ 群に分類して比較 すると, $\mathrm{n}($ (一)群では差が認められなかったが, $\mathrm{n}(+)$ 群では OK-432腫瘍内投与群が良好な傾向であった (図 4 ).

昭和51年から53年までの胃癌治瘑切除例の組織学的

図 4 胃癌治癁切除例 stage III における OK-432庫 瘍内投与群と非投与群の累積生存率

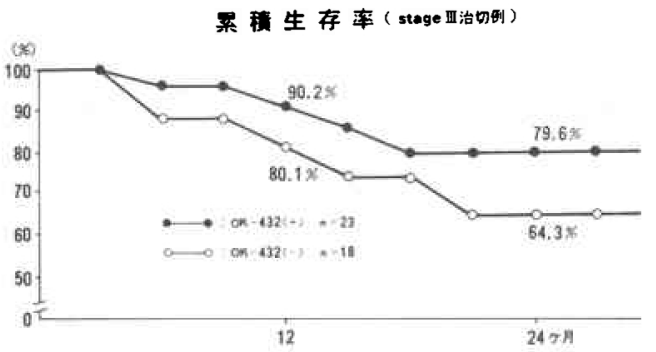

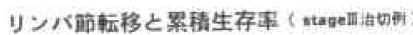

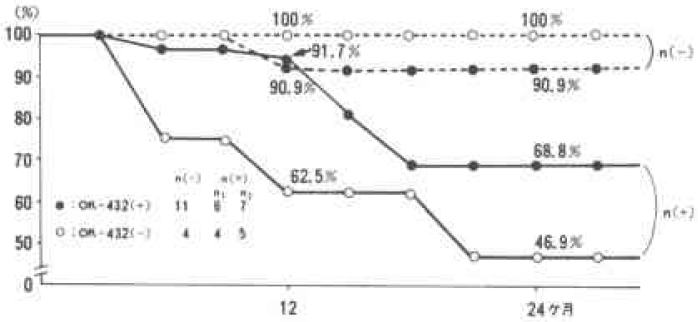

図 5 胃癌治瘁切除例 ( $\mathrm{n}_{0}$ および $\mathrm{n}_{1}$ 症例) におけるり ソパ節郭清度別の累積生存率

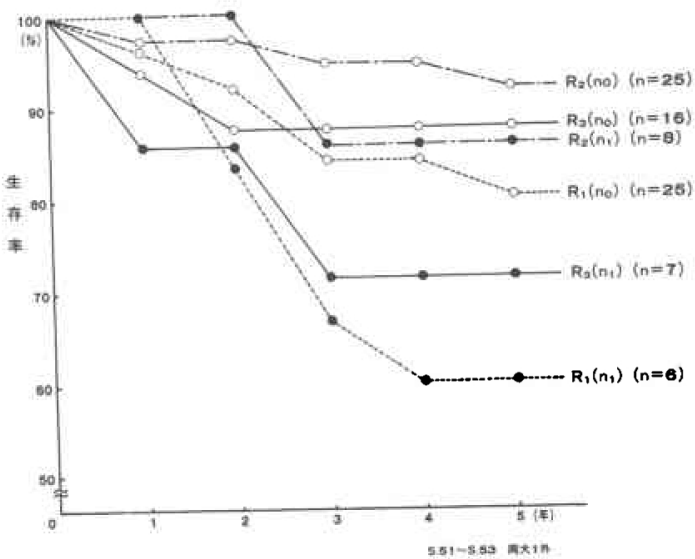

リンパ節転移度 $\mathrm{n}_{0}$ 例扣よび $\mathrm{n}_{1}$ 例で, 浆膜浸潤を考虑せ ずに, Rナンバー別に 5 年生存率を比較すると, $\mathrm{n}_{0}$ 例, $\mathrm{n}_{1}$ 例いずれも R2，R3，R1 の順に良好な傾向を示した (図 5 ).

\section{4. 考察}

担癌生体が腫場に対して，主にT細胞を中心とする 細胞性免疫による免疫監視機構を有し, 担癌荿器所属 リンパ節は癌の進展に対してバリヤーの働きをしてい るという報告が散見される ${ }^{10)}$.

suppressor 活性执よび cytotoxic 活性を同時にも つ OKT $8+$ 細胞は, 組織二重染色により, cytotoxic T 細胞あるいはその precursorであ万うと判明した。し かしながら，増加が認められた転移陽性リンパ節では， 二重染色により suppressor $\mathrm{T}$ 細胞之判定できるすの むあり，抗腫煌能への関与は少ない可能性があった。 逆に OKT $4+$ 細胞はT 細胞領域で多数を占め, 免疫賦 活剤腫瘍内投与群で増加することから，免疫応答への 関与が強く示唆された。第 3 群リンパ節では，第 1 群 リンパ節に比較して， OKT $4^{+}$細胞数が多く、リンパ節 反応様式でも，予後良好の指標である sinus histiocytosis や paracortical hyperplasia の頻度が高く， また， $\mathrm{n}_{0}$ おょひび $\mathrm{n}_{1}$ 例で $\mathrm{R}_{3}$ よりも $\mathrm{R}_{2}$ の成績が良好で あったことから，第 3 群リンパ節すなわち遠位のリン パ節には，第 1 群リンパ節よりも比較的免疫応答能そ して抗腫煌能が温存されているものと推測された。

$\mathrm{NK}$ 細胞に反応する各抗体陽性細胞はT 細胞系のリ ン八球に比較して, 少数であり, リンパ節リンパ球の NK 活性が低値を示すこと ${ }^{11)}$ と相関し，抗腫場能への 関与が少ないものと考兄られた。またこれらの Leu $7^{+}$, Leul1b ${ }^{+}, \mathrm{OKM}^{+}, \mathrm{OKT} 10^{+}$各細胞は分布形態 が異なり，機能あるいは成熟度に差があるものと示唆 された ${ }^{12)}$.

こういった natural history では微力と思われるリ ンパ節の免度学的抗腫瘍能を増強するため, 免疫賦活 剤の腫㑥内投与により, sinus histiocytosis や paracortical hyperplasia が増加し，抗腫場能を阻害する 方向に働くと考えられているB 細胞優位の follicular hyperplasia は減少した。ささらに，小数ではあるが, 癌 巣や転移陽性リンパ節の癌細胞に变性壊死像がみられ た。これらのリンパ節の免疫組織学的検索の結果, $\mathrm{OKM1} 1^{+}$細胞や OKT4+細胞の増加により，抗原認識機 構の賦活化が, また, IL-2 receptor ${ }^{+}$細胞の増加により， 活性化 T細胞の增加や Lymphokine Activated Killer (LAK) 細胞 ${ }^{13)}$ との関連性が示唆された。 また，免疫㒃 
活剂腫痬内投与群は非投与群に比較して，2 生率の向 上がみられたことからも，免疫賦活剂腫瘍内投与は所 属リンパ節の抗腫㻛能を増強するものと思われた。

したがって，リンパ節転移のほとんどない比較的早 期の胃癌では, $\mathrm{R}_{3}$ の必要性に疑問があり，かえって, $\mathrm{R}_{\mathbf{2}}$ の郭清により第 3 群リンパ節を残し，その抗腫瘍能 に期待することが，胃癌の予後を良くする可能性があ ると考觉られた。

\section{5. 結 語}

1）胃癌所属の転移陰性 リンパ節や遠位リンパ節に は, 潜在的な抗腫掦性免疫能が存在するが, 転移陽性 リンパ節では低下していた。

2）術前免度賦活剤腫膓内投与により,遠隔リンパ節 にまで, この抗腫掦能は増強され，生存率が向上した。 文 献

1）折田薰三：リンバ節と生体防御機構；悪性腫瘍手 術におけるリンパ節郭清の位置づけ。消外 6： $145-153,1983$

2）合地 明, 三輪恕昭, 松三 彰ほか：胃澏巣内免疫 賦活㓮注入時の局所組織所見ならびに全身的非特 異的免疫反応，消々兔疫 12：77-81，1984

3) Hsu SM, Raine L, Fanger $\mathrm{H}$ : Use of avidinbiotin-peroxidase complex (ABC) in immunoperoxidase techniques: A comparison between $A B C$ and unlabeled antibody (PAP) procedures. J Histochem Cytochem 29: $577-580,1981$

4）阿部雅明, 服部 進, 石田康生添か：モノクローナ ル抗体を用いた重染色法一免疫組織化学への応用 一. 病理と臨 $2: 1512-1514,1984$

5) Landay A, Gartland L, Clement LT: Characterization of phenotypically distinct subpopulation of Leu- $2^{+}$cells with suppresses $\mathrm{T}$ cell proliferative responses. J Immunol 131 : 2757-2761, 1983

6) Clement LT, Dagg MK, Landay A: Characterization of human lymphocyte subpopulations: Alloreactive cytotoxic $\mathrm{T}$ lymphocyte precursor and effector cells are phenotypically distinct from Leu-2 $2^{+}$suppressor cells. J Clin Immunol $4: 395-402,1984$

7）岡林孝弘, 堀見忠司, 平松 聡注：胃癌所属りン 八節の免疫組織学的検討一モノクローナル抗体に 上る解析一。臨免疫 $17: 660-668,1985$

8）胃癌研究会編：胃癌取扱い規約. (改訂第11版), 東 京, 金原出版, 1985, p4-29

9) $\mathrm{Si} \mathrm{L}$, Whiteside TL: Tissue distribution of human NK cells studied with anti-Leu-7 monoclonal antibody. J Immunol 130 : 2149-2155, 1983

10) Fisher B, Saffer E, Fisher ER: Studies concerning the regional lymph node in cancer. IV. Tumor inhibition by regional lymph node cells. Cancer 33:631-636, 1974

11) Vose BM, Vankey F, Argov $S$ et al : Natural cytotoxicity in man: Activity of lymph node and tumor-infiltrating lymphocytes. Eur J Immunol 7:753-757, 1977

12) Abo T, Miller CA, Gartland GL et al: Differentiation stages of human natural killer cells in lymphoid tissues from fetal to adult life. J Exp Med 157 : 273-284, 1983

13) Grimm EA, Mazumder A, Zhang $M Z$ et al: Lymphokine activated killer cell phenomenon. Lysis of natural killer resistant fresh solid tumors by interleukin 2 activated autologous human peripheral blood lymphocytes. J Exp Med 155 : 1823-1841, 1982 